\title{
Afinando silêncios: potencialidades de escolas outras na atualidade do presente
}

\section{Fine-tuning silences: the potential of another school in present}

\author{
Juciara Guimarães Carvalho ${ }^{1}$ \\ Jackeline Rodrigues Mendes ${ }^{2}$
}

\begin{abstract}
Resumo
Esse texto tem como propósito problematizar as territorializações da escola neoliberal, que se entranha cada vez mais no cenário brasileiro, gerando visibilidade às relações temporais e espaciais, não dissociáveis, de suas práticas escolares, intensificadas por um contexto de pandemia. Isso implica inevitavelmente e diríamos urgentemente pensar sobre escolas outras que desterritorializem essa lógica neoliberal e potencializem modos outros de fazer pulsar a vida, de habitar tempos e espaços outros e de constituir formas de vida escolares outras. Algo contrário a qualquer processo de reterritorialização neoliberal que intensifica e acelera as desigualdades de vidas. Com isso, não se trata de propor um modelo de escola, menos ainda, considerar a escola como sendo uma tela de computador e professores os mais novos influencers digitais, mas potencializar que outros arranjos pulsem diferentemente em nosso fazer escola na escola, principalmente na atualidade do presente. Trata-se de afinar os silêncios que nos habitam, alguns deles fortemente invisibilizados pelas práticas dominantes, e educar a atenção corpórea para perceber que a quietude inquietante, causada pelo isolamento social, pode nos ensinar algo. A saber, a necessidade de desacelerar, de ir mais devagar, de perceber que a força mortífera, caótica e devastadora de uma pandemia nos colocou para pensar sobre os valores da vida, das vidas escolares, mas também produziu forças inventivas gerando possibilidades e resistências para compor outros acordes vitais, ainda não pensados e vividos em nossos assujeitamentos. Essa composição músico-textual foi dividida em dois movimentos: no primeiro, problematizamos as práticas que decorrem do neoliberalismo escolar e, no segundo, discutimos sobre as potencialidades ao desestabilizar o território chamado escola, pensadas a partir da composição de outros ritmos escolares.
\end{abstract}

Palavras-chave: Educação; Escola; Slow School; Slow Movement

\begin{abstract}
This text aims to problematize the territorialization of the neoliberal school, which increasingly enters the Brazilian scenario, generating visibility in temporal and spatial relations, not dissociable, from its school practices, intensified by a pandemic context. This inevitably and urgently implies to think of other schools that deterritorialize this neoliberal logic and enhance other ways of making life pulse, inhabit other times and spaces and constitute other school forms of life. Something contrary to neoliberal reterritorialization process that intensifies and accelerates life inequalities. It is not a matter of proposing a school model, still less, considering a school as a computer screen and teachers how the newest digital influencers, but to enhance that other arrangements pulse differently in our work at school, especially in the present. It is about tuning the silences that inhabit us, some of them strongly invisible by the dominant practices, and educating a bodily attention to realize that the disturbing stillness caused by social isolation, can teach us something. We need to slow down, we need to go more slowly, to realize that the deadly, chaotic and devastating force of a pandemic placed us to think about the values of life, of school lives, but also produced inventive force generating possibilities and resistances to compose other chords vital, not yet thought and lived in our subjections. This musician-textual composition was divided into two movements:
\end{abstract}

\footnotetext{
${ }^{1}$ Doutoranda pela Faculdade de Educação da Universidade Estadual de Campinas (Unicamp), Campinas, Brasil. E-mail: juciaragcarvalho@gmail.com

2 Profa.Dra. da Faculdade de Educação da Universidade Estadual de Campinas (Unicamp), Campinas, Brasil. E-mail: ndanda10@gmail.com
} 
first, the problematization about the practices that result from school neoliberalism; second, the discussion about the destabilizing potentials in the school with the composition of other school rhythms.

Keywords: Education; School; Slow School; Slow Movement

\section{QUANDO AFINAMOS SILÊNCIOS, FORÇAS VIBRAM...}

“A família, a escola, os outros, todos elegem de nós uma centelha promissora, um território em que poderemos brilhar. Uns nasceram para cantar, outros para dançar, outros nasceram simplesmente para serem outros. Eu nasci para estar calado. Minha única vocação é o silêncio. Foi meu pai que me explicou: tenho inclinação para não falar, um talento para apurar silêncios. Escrevo bem, silêncios, no plural. Sim, porque não há um único silêncio. E todo silêncio é música em estado de gravidez" (Couto, 2016, p. 13, grifos nossos).

Mwanito, o afinador de silêncios, personagem do escritor moçambicano Mia Couto, presente na obra Antes de nascer o mundo (2009), instiga-nos a realizar esse ousado, trabalhoso e árduo exercício de afinar silêncios. Isso porque não requer uma resolutividade musical ou uma consonância que os apaziguem ou a produção de um som universal, mas a sensibilidade para ter atenção à quietude inquietante, os fluxos silenciosos, os gestos e expressões e, os acontecimentos que nos chegam com o silêncio. Essa prática é realizada por Mwanito quando se sentava no chão perto de seu pai chamado Silvestre Vitalício, que se recostava na cadeira na varanda, e permaneciam os dois em silêncio. Depois de algum tempo, o pai lhe falara: “- Este é o silêncio mais bonito que escutei até hoje. Agradeço-lhe, Mwanito" (Couto, 2016, p. 14).

Por outro lado, Mwanito parece também denunciar sobre as expectativas, criadas pela família, sociedade, escola e Estado, para tornar-se um sujeito de talento, bem sucedido, que produz mais em menos tempo e que seja flexível às demandas de um mundo que em sua própria narrativa não existe mais. Mas como faleceu o mundo? - indagava Mwanito. E seu pai respondera: - $O$ mundo acabou mesmo antes do fim do mundo... A vida é demasiado preciosa para ser esbanjada num mundo desencantado (Couto, 2016). Em outras palavras, a personagem parece denunciar um território 3 cujo "brilho" se constitui a partir de uma lógica neoliberal e, entre seus processos de territorialização podemos destacar a "mercadização" do ensino, a concepção de educação utilitarista, o

\footnotetext{
${ }^{3}$ Pensando com Deleuze e Guattari, a noção de território é considerada como sendo sempre provisório, pois "não há território sem um vetor de saída do território e não há saída do território, ou seja, desterritorialização, sem, ao mesmo tempo, um esforço para se reterritorializar em outra parte". Disponível em: <http://stoa.usp.br/prodsubjeduc/files/262/1015/Abecedario+G.+Deleuze.pdf>. Acesso: 25. mai. 2020.
} 
Guimarães, J. \& Rodrigues, J. (2020). Afinando silêncios: potencialidades de escolas outras na atualidade do presente. Revista Latinoamericana de Etnomatemática, 13(1), 334-354. DOI:

10.22267/relatem.20131.50

empobrecimento dos serviços públicos e o sistema educacional a serviço da competitividade econômica.

Segundo Laval (2019, p. 21), “o neoliberalismo se apresenta à escola, e ao restante da sociedade, como uma solução ideal e universal para todas as contradições e disfuncionalidades, mas na verdade é um remédio que alimenta o mal que deveria curar". Nesse sentido, nossa intenção é problematizar as territorializações da escola neoliberal, que se entranha cada vez mais no cenário brasileiro, gerando visibilidade às relações temporais e espaciais (não dissociáveis), de suas práticas escolares, intensificadas por um contexto de pandemia. Isso implica inevitavelmente e diríamos urgentemente pensar sobre escolas outras que desterritorializem ${ }^{4}$ essa lógica neoliberal e potencializem modos outros de fazer pulsar a vida, de habitar tempos e espaços outros e de constituir formas de vida escolares outras. Algo contrário a qualquer processo de reterritorialização neoliberal que intensifica e acelera as desigualdades de vidas. Com isso, não se trata de propor um modelo de escola, mas potencializar que outros arranjos pulsem diferentemente em nosso fazer escola na escola, principalmente na atualidade do presente.

Trata-se de um exercício para permitir-se sentir o que nos acontece quando a força mortífera, caótica e devastadora de uma pandemia provoca uma parada brusca e inesperada. Quando as medidas de isolamento social provocaram o fechamento das escolas e das universidades públicas e privadas, dos pequenos e grandes comércios e a interdição de transportes. Deparamos com os silêncios das ruas dos quais resultaram curiosamente em passagens de animais silvestres no centro das cidades, praias com águas mais claras e níveis menores de poluição. Uma quietude acalentadora para alguns viventes e por outro lado, ensurdecedora para muitos. Sobre o imperativo do \#fiqueemcasa experienciamos o tempo livre; livre do tiquetaquear acelerado do cotidiano, do consumo excessivo, das agendas abarrotadas, das viagens e eventos, das atividades contemporâneas de lazer. Percebemos o valor da vida, o tempo desocupado, o ócio e para muitos o tédio, a violência e a fome. Para alguns, um tempo para cuidar de

\footnotetext{
${ }^{4}$ Segundo Deleuze e Guattari (1997), é o processo de desterritorialização que constitui e estende o próprio território, faz fugir do território. Ou ainda, quando paramos de contemplar o escoamento de um fluxo laminar com direção determinada, e somos arrastados por um fluxo turbilhonar; quando nos engajamos na variação contínua das variáveis, em vez de extrair dela constantes, (...), não paramos de nos reterritorializar num ponto de vista, num domínio, segundo um conjunto de relações constantes; mas, segundo o modelo ambulante.
} 
si e ocupar-se consigo mesmo, realizando atividades que não conseguíamos fazer com o tempo que se vende; nos re-inventamos e re-existimos, e continuaremos a fazer isso.

De um lado, afrouxamos os ponteiros do relógio, mas intensificamos as desigualdades de vidas. Todas, todas as vidas importam. Talvez, percebemos valores, tempos e espaços outros pulsarem em nossas formas de vida, possibilitando a constituição de uma vida outra, pós-pandemia. Uma verdadeira vida. Talvez, pensamos nos usos que fazemos das palavras tempo e espaço em nossas práticas e, em especial, nas práticas escolares envolvendo o fazer/aprender matemática nesses tempos e espaços. Uma vez que as práticas escolares marcadas por tempos e espaços compõem o próprio olhar desse fazer, educar, ensinar e aprender matemática. Insistimos em problematizar sobre as vidas escolares. Talvez, elas experimentam tempos e espaços outros por vir criando outras condições de existência às formas de vida escolares e à própria instituição escola. Isso não implica considerar a escola como sendo uma tela de computador e professores os mais novos influencers digitais. Ou ainda, intensificar desigualdades de vidas a partir de propostas neoliberais que tentam transportar o seu modus operandi para o ensino remoto.

Do outro lado, percebemos que uma força negativa também produz, a saber, forças inventivas que produzem possibilidades e resistências para compor outros acordes vitais, ainda não pensados e vividos em nossos assujeitamentos. Afinal, os efeitos da pandemia tornaram-se ainda mais provocativos ao criarem ritmos não-lineares e espaços outros amalgamados no interior de nossas práticas socioculturais. É inevitável colocarmos para funcionar diferentes arranjos e combinações, criando conexões outras que, em metamorfose permanente, potencializam constelações outras para a Educação, na recusa de tornar a escola e a universidade em uma empresa. Assim, indagamos como seria afinar os silêncios que habitam a escola nesse momento de pandemia? Como seria desconcertar esse modelo de escola neoliberal? Que sujeitos desejamos com esse desconcerto? Certamente, antes da busca por diferentes respostas essas questões nos apresentam um problema a ser discutido.

Para tanto, essa composição músico-textual será dividida em dois movimentos: no primeiro, problematizamos as práticas que decorrem do neoliberalismo escolar. No segundo, discutimos sobre as potencialidades ao desestabilizar o território chamado 
Guimarães, J. \& Rodrigues, J. (2020). Afinando silêncios: potencialidades de escolas outras na atualidade do presente. Revista Latinoamericana de Etnomatemática, 13(1), 334-354. DOI:

10.22267/relatem.20131.50

escola, pensadas a partir da composição de tempos e espaços outros que emergem enquanto potência de criação.

\title{
2. UM TERRITÓRIO PANTANOSO DO CONHECIMENTO ÚTIL
}

\author{
“- Me ensina a ler, Zaca. \\ - Se quiser aprender, aprenda sozinho. \\ Aprender sozinho? Impossível (...). Em Jesusalém não entrava livro, nem \\ caderno, nem nada que fosse parente da escrita. \\ - Pois eu o ensino a ler. [disse Ntunzi, irmão mais velho de Mwanito] \\ E foi assim que começaram as primeiras lições. Uns aprendem por cartilhas, \\ em salas de aula. Eu me iniciei soletrando receitas de guerra. A minha \\ primeira escola era um paiol. As aulas ocorriam na penumbra do armazém, \\ nos longos períodos em que Zacaria estava ausente, aos tiros pelo mato. \\ Eu já juntava palavras, tecendo frases e parágrafos. Rapidamente notei que, \\ em vez de ler, a minha tendência era entoar como estivesse perante uma \\ pauta de música. Não lia, cantava, redobrando a desobediência. \\ - Não tem medo de sermos apanhados, Ntunzi? \\ - Você deve ter medo é de não saber. Depois da leitura, vou ensinar-lhe a \\ escrever”. (Couto, 2016, p. 40-41)
}

Nesse movimento de escrita problematizaremos sobre os processos de territorialização de uma nova forma escolar, a escola neoliberal. Trata-se de percorrer os modos como se tem praticado esse novo modo de fazer escola e, que pode ser acionado pela fala da personagem Zacaria: “- Se quiser aprender, aprenda sozinho”. Em outras palavras, o neoliberalismo escolar funciona pela lógica que individualiza o saber como sendo escolhas do indivíduo, e por sua vez, o responsabiliza pela produção de seu próprio "capital humano"5 a ser vendido no mercado de trabalho. Para Veiga-Neto (2000), tratase de uma nova tática: a maximização da liberdade individual - de modo que cada um pense que é livre para fazer suas escolhas -, funciona como condição de possibilidade para que se dê passagem do "governo da sociedade" (no liberalismo) para o "governo dos sujeitos" (no neoliberalismo). A produção de um "sujeito-cliente ao qual (se diz

5 A noção de capital humano foi discutida pelo economista estadunidense Gary Becker, na obra Human Capital:a theoretical and empirical analysis, with special reference to education (1964), em que argumenta que o sujeito deve desenvolver, ao máximo, sua capacidade de ser empresário de si mesmo. No entanto, segundo Laval (2019), essa metáfora leva uma visão muito empobrecida dos resultados do 'investimento no saber', considerado, na essência, uma fonte de ganho de produtividade. "Essa noção pode englobar os vários trunfos que o indivíduo pode fazer valer no mercado e vender aos empregadores como fonte potencial de valor; oferece uma justificativa econômica às despesas com educação; tem a vantagem de traduzir o enfraquecimento do vínculo entre diploma e emprego e justificar a maior seletividade dos empregadores em um período em que a inflação de títulos tende a fazer crescer a importância dos componentes "informais", sobretudo, a origem social, na análise da "empregabilidade" dos assalariados" (Laval, 2019, p.51). 
que) se oferecem infinitas possibilidades de escolha, aquisição, participação e consumo" (Veiga-Neto, 2000, p. 199).

Esse cenário modifica as concepções de Educação e de escola deslocando-as, portanto, à lógica econômica. Para Laval (2019), essas mutações estão associadas a três tendências indissociáveis: a) a desinstitucionalização, que transforma a instituição em uma “organização flexível”, em uma "empresa educadora"; b) a desvalorização, na qual ocorre a transmutação progressiva de todos os valores em mero valor econômico; c) a desintegração, que insere uma concepção consumidora da autonomia individual. Isso implica dedicar atenção às práticas que são e serão realizadas a partir desse território pantanoso e perigoso, que degringola para uma educação escolarizada privada. Para tanto, cada vez mais é pertinente interrogarmos de que escola e universidade consideram esse modelo neoliberal, para quem elas se destinam, quais seus objetivos, como e onde elas funcionam e, que sujeitos desejam constituir.

Laval (2019) afirma que a concepção de educação nesse novo modelo neoliberal apresenta duas dimensões: ela é ao mesmo tempo utilitarista na ideia que confere ao saber e, liberal no modo de organização da escola, ou seja, pelo lugar que ocupa no mercado do ensino. A onda neoliberal, que a partir dos anos 1980 se entrelaça nas políticas dos países ocidentais, atravessa também a educação inserindo um modelo que subordina a produção de conhecimento à lógica econômica como um 'indicador de competitividade' do sistema econômico e social. Assim, "a educação tornou-se um 'fator de atração' de capitais cuja importância vem crescendo nas estratégias 'globais' das empresas e nas políticas de adequação dos governos" (Laval, 2019, p. 18).

$\mathrm{O}$ que se torna pantanoso com as territorializações estabelecidas com esse modelo para com a educação dizem respeito à sua estrita relação econômica, ou seja, a educação como produto e o trabalho como mercadoria. Isso coloca em jogo muitos aspectos que modificam o sistema normativo da sociedade e seus sistemas de educação, a saber, "os únicos valores sociais legítimos são a eficiência produtiva, a mobilidade intelectual, mental e afetiva, e o sucesso pessoal" (Laval, 2019, p.39). A própria relação com o saber é modificada ao passo que o conhecimento é reduzido à aplicação daquilo que é útil, no exercício de uma profissão ou de uma atividade considerada socialmente útil. Esse sentido utilitarista é acionando, de um lado, a partir da forte concorrência dentro de um espaço globalizado e, de outro lado, pelo papel cada vez mais determinante da 
Guimarães, J. \& Rodrigues, J. (2020). Afinando silêncios: potencialidades de escolas outras na atualidade do presente. Revista Latinoamericana de Etnomatemática, 13(1), 334-354. DOI:

10.22267/relatem.20131.50

qualificação e do conhecimento na concepção, na produção e na venda de bens e serviços.

Com um olhar distraído isso não parece ser um problema, mas a questão é como determinamos o que é ou não útil, útil para quem e a serviço de que? Ao pagar o preço de um "sujeito flexível" para atender as demandas do mercado parece que se deixa de praticar um conhecimento para a vida. Um conhecimento que cria condições para mundos outros e de combate às desigualdades de vidas, que possibilita criar movimentos de desnaturalização, suspeição e de problematização dos agenciamentos que faz com que sejamos aquilo que somos. Segundo Laval (2019), a industrialização e a mercadorização da existência estão redefinindo o indivíduo como um ser essencialmente econômico, ele é considerado como um "recurso humano" e um consumidor que deve ser atendido.

O problema "diz respeito aos grandes interesses econômicos que transformam a educação em mercado e as escolas em fábricas de competências" (Laval, 2019, p. 148). Assim, a concepção de escola também se modifica para atender a lógica subtendida, motivo pelo qual se cria a necessidade de reformas educacionais com o intuito salvacionista que está atrelado ao discurso da inovação, mas também da precarização do valor escolar e profissional dos indivíduos e o ataque ao ensino público. $\mathrm{O}$ jogo estabelecido é ao mesmo tempo cultural e político. Afinal, nesse jogo, "o ensino deve armar os estudantes com competências de organização, comunicação, adaptabilidade, trabalho em equipe, resolução de problemas em contextos de incerteza" (Laval, 2019, p.41). Embora não seja o objetivo aqui proposto, podemos alertar para como esses discursos podem ser acionados em propostas como a Base Nacional Comum Curricular, o Projeto de Vida, o projeto Future-se, a formação permanente e o ensino à distância.

A relação com o saber na escola se modifica, pois

"não é mais um bem que se adquire para fazer parte de uma essência universal do humano, como no antigo modelo escolar - que diga-se de passagem, reservava esse bem supremo a poucos - , mas um investimento mais ou menos rentável para indivíduos com dotes materiais e intelectuais desiguais. Os valores que constituíam o mundo escolar foram substituídos por novos critérios operacionais: eficácia, mobilidade, interesse" (Laval, 2019, p. 48).

Para esse modelo educacional o que interessa são os conhecimentos úteis para torná-los produtos possibilitando ampliar a concorrência generalizada. Fato este que, resultou o 
deslocamento do centro de gravidade (do capitalismo) $d a$ produção para o produto, cuja circulação dependerá do mercado (Veiga-Neto, 2000).

Por isso o imperativo, evidenciado por Laval (2019, p. 72), de que "a escola deve abandonar tudo o que se assemelhe a uma acumulação de saberes supérfluos, impositivos, maçantes (...); deve ater-se às competências básicas comercializáveis”. O período neoliberal insere uma nova arte de governar que desloca o entendimento de uma educação como gasto para o de investimento. Nesse sentido, "o Estado passa a ser pensado como o responsável pela construção social de novas necessidades e maiores competências" (Veiga-Neto, 2000, p. 197), funcionando pela lógica da empresa.

Em uma fase mais madura da sociedade do mercado, também considerada por Laval (2019) como mutações do capitalismo, emergem as práticas de desobrigação do Estado, de privatização das empresas públicas e a transformação dos serviços públicos em quase empresas, da ampliação dos processos de mercadorização ao lazer e à cultura, da mobilização geral dos assalariados numa "guerra econômica" generalizada, da contestação das proteções dos assalariados e da disciplinarização pelo medo do desemprego. Quem deve pagar a conta disso tudo? "Dependendo do ganho esperado, o financiamento deve ser dividido entre o Estado, a empresa e o indivíduo" (Laval, 2019, p. 53).

Nesse novo contexto, a instituição escolar deve constituir um sujeito-cliente que seja flexível, adaptável, às demandas mais variadas do mundo neoliberal, mas, sobretudo, que apresente as competências exigidas para fazer a maquinaria econômica funcionar. Para tanto, parece que a escola neoliberal continua apostando em práticas como o quadriculamento do espaço, a espacialização do tempo, a disciplinarização dos corpos, o engessamento do currículo disciplinarizado, a avaliação etapista e seletiva do conhecimento, a meritocracia e o consumo. Além disso, as práticas de empresariamento das escolas emergem com as propostas de gestão do "capital humano", da lógica do controle, da inovação tecnológica e do acompanhamento da evolução econômica.

Um desdobramento possível desse processo neoliberal é a banalização de uma Fast School, que ao ser comparada às vivências modernas do Fast-Food, oferece um cardápio rápido de conteúdos e procedimentos. Pensemos sobre essas semelhanças. Maurice Holt (2006) critica o "modelo hambúrguer de educação" e a "camisa de força curricular" que constituem a Fast School, ou seja, esse modelo de escola que se 
Guimarães, J. \& Rodrigues, J. (2020). Afinando silêncios: potencialidades de escolas outras na atualidade do presente. Revista Latinoamericana de Etnomatemática, 13(1), 334-354. DOI:

10.22267/relatem.20131.50

preocupa com o produto final padronizado baseado em testes e metas, como no caso da comida em que o hambúrguer é padronizado e se parece com todos os outros que produzem. Assim, "a teoria do hambúrguer é simples - colocar um pedaço de carne frita entre as duas metades de um pão e pronto, o sabor é delicioso! A prática é um determinando conjunto de procedimentos, e não é da conta do consumidor saber de onde vem a carne" (Holt, 2006, p. 91).

A Fast School reforça as práticas neoliberais que estão emaranhadas no tecido social. Sem muito esforço podemos colocar em relevo suas reverberações tais como: a aceleração do ensino - no que diz respeito a aprender mais em menos tempo, se isso for mesmo possível; o apelo às aulas-espetáculos, aos vídeos curtos postados no Youtube, as lives estreadas pelos professores como sendo os mais novos influencers e ao $e$ learning. O que revela uma caricatura da produção de conhecimento à serviço da produção capitalística. Todos os esforços são realizados para que não se esgote a paciência do sujeito-cliente e que apresente o conhecimento útil desejado. Para utilizar a expressão de Holt (2006), o que importa é uma refeição ou aula satisfatória. Também podemos assinalar a qualificação dos mais adaptáveis e rentáveis, os quais receberiam mais investimentos.

Contudo, o que é importante reter é como essas práticas e tecnologias estão presentes nas formas de vida escolares e acabam por intensificar as desigualdades de vidas a partir de propostas neoliberais. Haja vista, o momento de pandemia oportuno para transportar o seu modus operandi ao ensino remoto, o qual cria novos espaços tempos mediados pela tecnologia, replicando desigualdades, seja em relação aos produtores de conteúdo, os quais se movem em uma produção que tem como objetivo atuar na condução dos sujeitos de acordo com interesses marcados por processos de mercantilização e consumo, como em relação às formas desiguais de acesso. É preciso examinar a questão em uma camada menos aparente, pois além de estabelecerem um novo regime de dominação, elas estão mudando até mesmo nossas percepções acerca do espaço e do tempo. (Veiga-Neto, 2000). Vamos nos limitar a levantar algumas questões, um tanto genéricas, tomando duas práticas: uma, a escrita e a leitura (da cultura eurocentrada) a partir do uso do computador ou celular; e a outra, o e-learning (educação on-line).

Certamente, a experiência da personagem Mwanito com a escrita e leitura fora diferente, pois suas receitas de guerra pôde o ensinar também a cantar a partitura do 
mundo desobedecendo às regras de uma restrita leitura e escrita de uma determinada língua. A guerra na atualidade do presente é outra, mas também nos ensina a ler e escrever sobre mundo diferentemente. Segundo Veiga-Neto (2000, p. 210) nossa relação espacial e temporal se modifica no mundo da hipertextualidade, pois "ao mesmo tempo em que parece expandir o texto, é capaz de trazer todos os textos para um só ponto". Contudo, essa nova topologia esconde certos pântanos, como afirma Pierre Lévy (1996, p. 37): "navegar em um hipertexto significa, portanto, desenhar um percurso em uma rede que pode ser tão complicada quanto possível. Porque cada nó pode, por sua vez, conter uma rede inteira".

Isso parece fortalecer o discurso da aprendizagem autônoma na qual o sujeito-cliente deve consumir as informações e ser capaz de alimentar a produção do mercado. Trata-se da sutil passagem, apresentada por Laval (2019), de um modelo de ensino para um modelo de aprendizagem, ligando-se, portanto, às sedutoras propostas do e-learning. Afinal, as vantagens individuais e econômicas são evidentes, como afirma o autor:

"alguns se precipitam e veem essas ferramentas como alavancas para uma evasão escolar geral: por que se deslocar, se sujeitar a horários restritivos, aceitar a autoridade de um professor, quando se pode aprender em casa, no momento que se quiser, em pé de igualdade com os colegas?” (Laval, 2019, p. 145).

Por outro lado, "dispensa a necessidade de levantar as paredes, oferece grande flexibilidade de uso e globaliza oferta e demanda" (Laval, 2019, p. 147).

Nesse sentido, a educação on-line proposta pela lógica neoliberal serve também para enfraquecer as instituições públicas de ensino, modificar o papel do professor tornandoo coach, ausentar os poderes públicos, atender à demanda de poucos que podem pagar por ela. Devemos, portanto, desconfiar das soluções milagrosas que nos chegam ao sistema educacional, resistir as práticas que se distanciam da justiça social e desterritorializá-las a favor da permanência de uma educação pública, de qualidade e democrática. Assim, precisamos potencializar outros arranjos que pulsem diferentemente em nosso fazer escola na escola, modos outros de fazer pulsar a vida, de habitar tempos e espaços outros, de constituir formas de vida escolares outras, ainda não pensados e vividos em nossos assujeitamentos.

\section{TECENDO ENCANTAMENTOS DE ESCOLAS OUTRAS...}

“- E depois, Ntunzi? O que fez, o que aconteceu depois? 
Guimarães, J. \& Rodrigues, J. (2020). Afinando silêncios: potencialidades de escolas outras na atualidade do presente. Revista Latinoamericana de Etnomatemática, 13(1), 334-354. DOI:

10.22267/relatem.20131.50

Meu irmão subiu ao armário do quarto e lá estava a velha mala onde escondera os seus desenhos. Sacudiu a poeira para dar mais aparência às dezenas de rostos de nossa mãe. Todos diferentes, mas sempre os mesmos olhos enormes de quem está no mundo como numa janela: à espera de uma outra vida" [de uma vida outra] (Couto, 2016, p. 274).

A personagem Mwanito narra seu encantamento pela escola, seu "primeiro dia de aulas, o estranho sentimento de ver tantos meninos sentados numa mesma sala. Mais estranho ainda: era um livro que nos unia horas a fio, tecendo infâncias num mundo envelhecido" (Couto, 2016, p. 254). Seu fascínio pelas aulas não passou despercebido ao professor, que falava com paixão sobre a injustiça e contra os novos-ricos. Em uma saída com a turma os levou para conhecer um local onde um jornalista que denunciara os corruptos tinha sido assassinado. "No local, não havia monumento nem nenhum sinal de homenagem oficial. Apenas uma árvore, um cajueiro eternizava a coragem de quem arriscou a vida contra a mentira" (Couto, 2016, p. 254). Essa experiência coletiva marcou Mwanito, mas também a percepção de que o admirável professor não estava bem de saúde. Não demorou muito e anunciaram sua morte. "disseram depois que sofria da 'doença do século'. Que era mais uma vítima da 'pandemia'. Mas nunca pronunciaram o nome da enfermidade" (Couto, 2016, p. 255).

Esses encantamentos pela escola mostram a multiplicidade de combinações de narrativas que potencializam constituir escolas outras, desejando formas de vida escolares outras. Assim como, diferentes arranjos podem compor outras possibilidades de escrita, ao mesmo tempo literária, musical, cenográfica e dançante, que proporcionam condições de pensamento e atitudes mais igualitárias. Movimentos esses que nos exigem o deslocamento de uma escrita e leitura do mundo linear, hierárquica, eurocêntrica, patriarcal e sexista. E mais, o afastamento de um tempo de vida regulado necessariamente pela produção capitalística e pelo estriamento do espaço. Em outras palavras, ao considerar as práticas dominantes da sociedade e, portanto, da escola, queremos desestabilizar seu território a partir da composição de outros ritmos escolares. A quietude inquietante, do complexo momento de pandemia que vivemos, pode nos ensinar algo. Para tanto, como seria desconcertar esse modelo de escola neoliberal? Que sujeitos desejamos constituir com esse desconcerto? Antes de buscar por respostas provisórias, as quais poderiam ser discutidas por diferentes perspectivas, consideramos alguns apontamentos que ampliam a discussão proposta. Assim, realizamos o exercício de puxar um fio da rede e discutir seus efeitos. A saber, o que nos acontece quando 
sentimos a necessidade de desacelerar, de ir mais devagar? Quando afrouxamos os ponteiros relógios, livre do tiquetaquear acelerado do cotidiano, do consumo excessivo, das agendas abarrotadas, das viagens e eventos, das atividades contemporâneas de lazer. Quando, ironicamente, não sabemos o que fazer com o "tempo livre" das atividades cotidianas como ir à escola, à universidade, ao trabalho, à academia, às igrejas e templos e entre tantos outros espaços. O desafio torna-se ocupar esse tempo com lives, filmes, séries, livros e etc, considerando o desafio imposto de um isolamento social.

Talvez, a dificuldade reside em refletir sobre a falta de um tempo que seja nosso, diferente daquele o qual vendemos na forma de força de trabalho, de produção e de "capital humano". Com isso, não queremos isentar os diferentes tipos de violência implicados nesses processos como a violência doméstica, o tédio, a depressão, o desemprego em massa e a fome. A urgência é perceber o valor da vida, que todas elas importam, e nesse caso, pensar a vida das formas de vida escolares. Assim, torna-se pertinente problematizar o ritmo de nossas vidas que rompe com a fúria da velocidade cotidiana. Essa prática permite "controlar seus ritmos na qual é você quem decide em que velocidade deve andar em determinado contexto, pois estamos lutando pelo direito de determinar nosso próprio andamento"6.

Trata-se de encenar um movimento cuja problematização permite colocar o tempo moderno, o culto da velocidade e as práticas neoliberais em suspeição. O Slow Movement critica as formas atuais de globalização e apresenta um olhar atento para com o sistema capitalista (Honoré, 2005). Esse movimento foi inspirado pela resistência de Carlo Petrini à chegada do Fast Food, na Itália, nos anos de 1980. Segundo Honoré (2005), é preciso questionar nossa obsessão de fazer tudo mais depressa, pois o problema é que o nosso amor à velocidade, nossa obsessão em estar sempre fazendo cada vez mais em tempo cada vez menor foi longe demais; transformou-se num vício, numa espécie de idolatria para servir à economia e não o contrário. Por isso, "um mundo autenticamente Devagar [não necessariamente devagar, mas com outros ritmos] requer nada menos que uma revolução em nossos estilos de vida" (Honoré, 2005, p. 29). O Slow Movement se insere nas práticas cotidianas das atividades humanas como na escola, no trabalho, na alimentação, na medicina e no urbanismo praticando a

\footnotetext{
6 Trechos de uma entrevista concedida à Carl Honoré (2005) do italiano Carlo Petrini um dos grandes defensores da desaceleração e fundador do movimento internacional Slow Food.
} 
Guimarães, J. \& Rodrigues, J. (2020). Afinando silêncios: potencialidades de escolas outras na atualidade do presente. Revista Latinoamericana de Etnomatemática, 13(1), 334-354. DOI:

10.22267/relatem.20131.50

desaceleração. Para Honoré (2005), o Slow Movement é constituído de pessoas como você e eu, pessoas que querem viver melhor no moderno mundo da velocidade, sua filosofia pode ser resumida numa única palavra: equilíbrio. Afinal, podemos nos surpreender quando percebemos como somos governados pelo poder e a verdade do tique-taque, ou ainda, como somos subjetivados para dividir o tempo em unidades ainda menores, viver na compartimentalização do tempo, e fazer tudo mais depressa. $\mathrm{O}$ planejamento das ações faz com que tudo pareça desenrolado, mas, frequentemente, nos esquecemos do fio do tempo a desenrolar, do acontecimento da vida a viver. Muitas vezes o consideramos como sendo inimigo do tempo, um atraso, um imprevisto, algo improdutivo e até mesmo uma frustração.

O que é importante sublinhar sobre o Slow Movement é que ele oferece

"um caminho intermediário, uma maneira de associar a dolce vita ao dinamismo da era da informação. O segredo está no equilíbrio: em vez de fazer tudo depressa, fazer tudo na velocidade certa. Às vezes depressa. Às vezes devagar. Às vezes nem uma coisa nem outra. Viver Devagar significa nunca se afobar, nunca tentar ganhar tempo só para ganhar tempo. Significa manter-se calmo e imperturbável mesmo quando as circunstâncias nos obrigam a apressar as coisas" (Honoré, 2005, p. 309).

Trata-se de intervir pelo seu próprio tempo, seu próprio andamento, que dura a sua maneira. Contudo, isso não significa uma relação individualista e egoísta de perceber o próprio ritmo, mas que se está sempre inserido em um coletivo. Isso requer a coragem de viver uma verdadeira vida despojada das capturas do tempo cronos.

Diante desse contexto, desejamos desconcertar o modelo Fast School contrapondo-a com a ideia de uma Slow School, praticando uma Slow Education. Na análise realizada por Honoré (2005), as crianças não nascem obcecadas com velocidade e produtividade, somos nós adultos que as fazemos assim. Na escola aprendemos a empregar o tempo da maneira mais eficiente possível, pois em nosso mundo industrializado da escola o que importa são as avaliações do aproveitamento. A Fast School torna-se mais excludente e menos igualitária. Desse modo, ao trazer o Slow Movement para a Educação, ou seja, ao considerar uma educação pulsando em diferentes ritmos potencializam-se diferentes conexões com o conhecimento. É sobre levar uma vida escolarizada em harmonia com os seres humanos e não humanos.

Nas palavras de Holt (2006), o slow tornou-se uma metáfora de uma determinada maneira de abordar as questões práticas. Assim, a Slow School "não significa aprender, ler e calcular em velocidade reduzida para pessoas vagarosas, mas trata-se de filosofia, 
cultura, comunidade e escolhas éticas" (Holt, 2006, p. 91). A problematização da Slow School, constituída como uma narrativa cuja ênfase está no processo, pode ser frutífera ao potencializar a emergência de escolas outras. O estudante tem tempo para viver o tempo da escola constituindo uma forma de vida escolar outra, que não aquela apenas inventada para memorizar, realizar avaliações e avançar etapas, organizada em disciplinas e para atender às demandas do mercado de trabalho.

Isso não significa que não ocorram conflitos e tensionamentos entre essas práticas, pois as práticas slow não devem apenas ser praticadas por um pequeno grupo elitista ou ainda, para grupos de certos bairros e cidades ou para determinada faixa etária do início do processo de escolarização. Ainda é necessário desconcertar que slow não significa uma lentidão pura, ser improdutivo, preguiçoso e, ter um rendimento inferior ao esperado pelos testes escolares. Talvez, são esses motivos que se apresentam como dificuldades para praticar a Slow School de modo amplo e, também para resistir à fúria capitalista. Contudo, "basta lembrar quem venceu a corrida entre a tartaruga e a lebre. Ao passar a vida correndo, preocupados em atulhar cada vez mais coisas em cada horinha do dia, estamos nos estressando a um ponto que pode levar à ruptura" (Honoré, 2005, p. 14).

Assim, a lógica de funcionamento da Slow School se modifica, pois ela renova a si mesma. Da mesma maneira que as formas de vida renovam-se pelos seus próprios fluxos. Para Holt (2006), é nesse momento que a Slow School tem a sua verdadeira força, ela é uma grande "tenda", com espaço para uma grande variedade de abordagens e está ligada a uma vasta aceitação social, por meio de um currículo que visa oferecer a mesma oportunidade a todos. Em outras palavras, a própria concepção de Educação é mais inclusiva e igualitária visando à permanência do bem público. As competências são substituídas pelos bens culturais, os valores, que não podem ser medidos ou vendidos. Isso implica agir de modo contrário ao modelo educacional neoliberal, que visa atribuir um valor preciso ao resultado do processo de educação, tanto na avaliação das competências exigidas quanto no aspecto econômico.

Carl Honoré (2005) apresenta os exemplos singulares de alguns países que adotaram práticas da Slow School: na Finlândia, os estudantes enfrentam em número menor aos exames estudantis, mas quando são submetidos apresentam bons resultados; na Alemanha, os estudantes estabelecem uma relação diferente com o tempo escolar rígido 
Guimarães, J. \& Rodrigues, J. (2020). Afinando silêncios: potencialidades de escolas outras na atualidade do presente. Revista Latinoamericana de Etnomatemática, 13(1), 334-354. DOI:

10.22267/relatem.20131.50

e que salta de disciplina em disciplina; no Canadá, os estudantes de Toronto, de 4 a 12 anos, estabelecem uma relação com o conhecimento por si mesmos sem a obsessão com provas, notas e prazos; no Japão, os estudantes de Tóquio, de 6 a 19 anos, são afastados da disciplina marcial, da competição exaustiva e do clima sufocante que prevalece nas salas japonesas; na Grã-Bretanha, os sistemas de ensino começaram a buscar maneiras de aliviar a pressão sobre seus estudantes.

Segundo Holt (2006, p. 92), "não existe nenhuma regra rígida para a Slow School: cada uma pode ser diferente, como são diferentes as suas comunidades”. A relação com o saber está para além do conhecimento útil, no sentido utilitarista restrito, pois se trata de um conhecimento que arma para a vida no enfrentamento dos acontecimentos. Essa armadura para a vida é muito diferente do jogo neoliberal, apresentado anteriormente, cuja preocupação é armar os estudantes com competências para o trabalho. Consideramos que essa mudança de perspectiva destinada a uma preparação para a vida conduz entendimentos outros daquele que reduz o conhecimento útil vinculado estritamente à lógica de mercado.

Para tanto, retomamos o pensamento de Foucault (2011), presente no curso A coragem da verdade (1984), ao analisar a forma de vida cínica e, sobretudo, ao abordar questões sobre o ensino cínico, que tem uma concepção de formação e armadura para a vida. "É um tipo de aprendizado, aprendizado de resistência, de combate, aprendizado na forma de uma armadura dada para a existência, que caracteriza o ensino cínico" (Foucault, 2011, p. 182). Segundo Foucault (2011, p. 206), “o cinismo é a forma de filosofia que não cessa de colocar a questão: qual pode ser a forma de vida que seja tal que pratique o dizer-a-verdade?”. A forma de vida cínica coloca a própria vida em risco, não somente por um dizer-verdadeiro, mas pela própria maneira de viver. Nesse sentido, “o ensino cínico é um ensino simples, um ensino prático" (Foucault, 2011, p. 182).

Trata-se de um exercício de vida, uma prática da vida filosófica, que se distancia de uma história da filosofia das doutrinas dogmáticas e, considera, portanto, as formas de vida, uma história da vida filosófica como problema filosófico, ao mesmo tempo, ética e revolucionária (Foucault, 2011). Salvaguardo o contexto cínico na Grécia antiga, consideramos que a prática cínica pode ser relacionada às práticas de existência contemporâneas, no que diz respeito às possibilidades de gerar ferramentas conceituais e operacionais para as práticas na Slow School. Isso implica uma perspectiva filosófica, 
como prática de vida, para ampliar as discussões envolvendo as formas de vida escolares e encorajar que escolas outras possam pulsar.

Para elucidar sobre a prática cínica Foucault (2011) destacou cinco princípios praticados, ao mesmo tempo, por essa forma de vida, são eles: a filosofia como preparação para a vida; ocupar-se consigo mesmo; estudar apenas o que é realmente útil na e para a existência; tornar a vida conforme aos preceitos que formula e, mudar o valor da moeda. O primeiro deles é a chave do cinismo que se refere à questão da vida filosófica, mesmo que de forma escandalosa, imbricada na prática filosófica e no discurso filosófico. Esse movimento inclusive se diferencia da ciência, pois a prática filosófica deve ser uma espécie de exercício de vida enquanto a ciência utiliza o saber científico para validar suas formas de veridicção. Assim, "filosofar não é simplesmente uma forma de discurso, em seu princípio, mas também uma modalidade de vida" (Foucault, 2011, p. 206).

Para Foucault (2011), essa preparação para a vida implica no segundo princípio, ocuparse antes de tudo de si mesmo. É preciso todo um trabalho de si sobre si mesmo que exige o vínculo entre essas duas noções: conhecer-se a si mesmo e o cuidado de $\mathrm{si}^{7}$ para poder transformar-se. Ao evidenciar o cuidado de si está implicado o cuidado do outro, só há transformação de si mesmo a partir das provocações realizadas pelo outro. $\mathrm{O}$ cuidado de si como modo de existência é contínuo ao longo da vida, é uma atitude para transformar a vida possibilitando governar a si mesmo de outro modo, mesmo que seja governado pelos outros.

Para ocupar-se de si mesmo deve-se estudar apenas o que é útil na e para existência, o terceiro princípio. Foucault (2011) recorre ao texto de Diógenes Laércio que cita o exemplo de Diógenes, o Cínico, que

"se espantava com ver os gramáticos estudar tanto os modos de Ulisses e negligenciar os próprios, ver os músicos afinar tão bem sua lira e esquecer a afinação da alma, ver os matemáticos estudar o sol e a lua e esquecer o que têm sob os pés, ver os oradores cheios de zelo pelo bem falar ma nunca preocupados com bem fazer" (Foucault, 2011, p. 210)

\footnotetext{
${ }^{7}$ Não é nosso objetivo desenvolver sobre essas noções, mas para entender os seus funcionamentos na filosofia, a partir do pensamento socrático, sugerimos a leitura dos cursos ministrados por Foucault (1982) intitulado A Hermenêutica do Sujeito. Vale ressaltar que essas noções também atravessam suas obras posteriores como O Governo de Si e dos Outros (1983) e em A Coragem da Verdade (1984), essa segunda é abordada nessa discussão.
} 
Guimarães, J. \& Rodrigues, J. (2020). Afinando silêncios: potencialidades de escolas outras na atualidade do presente. Revista Latinoamericana de Etnomatemática, 13(1), 334-354. DOI:

10.22267/relatem.20131.50

Em outras palavras, a forma de vida cínica pratica o cuidado de si a partir dos conhecimentos que determinam como úteis para a vida. Trata-se de uma crítica ao enclausuramento criado pelos conteúdos da gramática, da matemática ou da música sinalizado já naquela época na cultura grega.

O quarto princípio diz respeito à condução da vida a partir dos preceitos formulados. "Só pode haver um verdadeiro cuidado de si se os princípios formulados como princípios verdadeiros forem ao mesmo tempo garantidos e autenticados pela maneira como se vive" (Foucault, 2011, p. 210). Para os cínicos é fundamental aliar o dizer ao fazer, ou seja, levar uma vida reta, sem mistura e sem subordinação. Trata-se de levar uma vida pública ao limite, pois para o cinismo "a verdadeira vida é a vida outra" (Foucault, 2011, p. 215) que possibilita a transformação de si e, consequentemente, do outro. Essa possibilidade gera o quinto princípio: "mudar o valor da moeda" (parakharáttein tò nómisma), onde a palavra nómisma é a moeda e nómos é a lei, isso implica que mudar o valor da moeda também é tomar certa atitude em relação ao que é convenção, regra e lei.

Contudo, a palavra parakharáttein (mudar, alterar) não se trata de desvalorizar a moeda, mas sim que "a partir de certa moeda que traz certa efígie, apagar a efígie e substituí-la por outra que representará muito e permitirá que essa moeda circule com seu verdadeiro valor" (Foucault, 2011, p. 199-200). Para os cínicos alterar a moeda é romper com o costume, quebrar regras, hábitos e leis que são impostas pelas formas de governar, ou seja, escapar dos modos de condução para re-existir. Assim, quando reinventa a si mesmo, alterando o valor da moeda, também se reinventa o outro. Talvez, seja importante evidenciar que no jogo cínico o valor da moeda não é o valor econômico, mas o valor para e da vida.

Nesse jogo não há coisas novas, mas transmutações ou transvalorizações que possibilitam a reinvenção. Para a forma de vida cínica o que importa é "dar a imagem do que, ao mesmo tempo, admitem e valorizam em seu pensamento e rejeitam e desprezam em sua própria vida" (foucault, 2011, p. 205). Desse modo, as grandes transformações não serão pela via política, marcada pelos vícios, mas pela ética e, produzir comunidades na ética pode constituir outras formas de vida em nome do bem comum e não dos interesses próprios. A atenção deve recair para que "a moeda não 
engane sobre seu verdadeiro valor, que lhe restituam seu valor impondo-lhe outra efígie, melhor e mais adequada" (Foucault, 2011, p. 200).

Diante da digressão e ao realizar essas aproximações com a forma de vida cínica não se quer com ela uma prática salvacionista, nem tampouco dialogar com a noção cínica deturpada que desautoriza a vida cínica, mas tatear possibilidades que nos permitiriam constituir uma forma de vida mais libertária e igualitária. Ou ainda, encontrar espaços para potencializar outras práticas produzindo novos efeitos. Afinal, a forma de vida cínica, o ensino cínico, potencializa uma experiência do pensamento e possibilita problematizar sobre a negligência das condições de existência das formas de vida escolares, ao submetê-las à maquinaria capitalística e assujeitá-las em suas práticas cotidianas desiguais.

Consideramos que o exercício cínico de "mudar o valor da moeda", entrelaçado aos outros princípios, contribui para a discussão do deslocamento e da inversão de práticas realizadas na Fast School. Uma vez que o movimento realizado pela Slow School tende a transmutar os valores da vida, praticar a relação com o conhecimento de modo diferente e escandalizar o culto à velocidade pelas formas de governar neoliberais. Afinal, nesse momento de pandemia e de uma desaceleração forçada, quantos sujeitos permitiram-se questionar e se escandalizar com esses modelos neoliberais? Quantos sujeitos conseguiram resistir às exigências impostas pelo modo de vida remoto? Estamos no olho do furacão e esse exercício cínico tem de ser uma prática diária, pois, se não, nos vemos capturados a todo momento. Assim, na Slow School a tentativa é "mudar o valor da moeda" permitindo outras condições de existência às formas de vida escolares, algo que nos permita combater o esgotamento que se vive, criar espaço outros a partir de conhecimentos que seriam negligenciados pela Fast School, fazer pulsar a transformação coletiva na relação com o outro e, onde a avaliação é a descoberta de uma forma de vida com inúmeras possibilidades.

Para Holt (2006), podemos optar por olhar para a escola a partir de dentro e focalizar a prática do currículo - o compromisso entre professor e estudante em um determinado contexto e os problemas que ele gera. O autor afirma que "o currículo não é uma questão de aplicar respostas pré-determinadas, mas de resolver esses problemas interativos de maneira a beneficiar todos os estudantes" (Holt, 2006, p. 94). Em outras palavras, na Slow School a invenção abre caminhos e permite reagir diferentemente às 
Guimarães, J. \& Rodrigues, J. (2020). Afinando silêncios: potencialidades de escolas outras na atualidade do presente. Revista Latinoamericana de Etnomatemática, 13(1), 334-354. DOI:

10.22267/relatem.20131.50

mudanças culturais, sociais e políticas, colocando para funcionar um "currículo abrangente que permite que a escolha seja feita entre grupos de matérias, em vez de entre disciplinas isoladas, fazendo uso de uma ampla variedade de estratégias de ensino" (Holt, 2006, p. 87) cujo foco está nas práticas culturais presente nas diferentes atividades humanas.

O mundo torna-se encantado e as formas de vida escolares podem encontrar seu próprio ritmo, vagar nas malhas do conhecimento, criar movimentos outros e compor uma forma de vida escolar diferentemente da já conhecida. "É uma questão de explorar o mundo e a reação que se tem diante dele, no ritmo de cada um" (Honoré, 2005, p. 300). Na perspectiva da Slow School, trata-se de viver aquilo que os músicos chamam de tempo giusto, nem rápido demais e nem lento demais, o andamento certo. Contudo, encontrar a velocidade certa pode não ser fácil, pois

“o andamento na música é um conceito escorregadio, mais próximo de uma arte do que de uma ciência. A velocidade em que é tocada uma peça musical pode variar de acordo com as circunstâncias - o estado de espírito do intérprete, o tipo de instrumento, a natureza da ocasião, o tipo de público, a sala, a acústica, a hora do dia e até a temperatura ambiente" (Honoré, 2005, p. 267).

Ao que parece, nossa dificuldade pode residir justamente na falta de uma velocidade certa e universal determinante para nossas atividades ou ainda, compreender que isso significaria substituir o culto à velocidade pelo culto à lentidão. Trata-se de permitir andamentos pulsantes que se movimentam a partir das sensibilidades e das diferenças.

Isso implica no difícil exercício de "manter-se calmo e imperturbável mesmo quando as circunstâncias nos obrigam a apressar as coisas" (Honoré, 2005, p. 309) e, consequentemente, de inserir modos de contracondutas que resiste às armadilhas criadas pela velocidade, pelo sentimento da falta de tempo, pela valorização da pressa e escassez do tempo. O valor do tempo para a Slow School passa longe de ser considerado um "recurso humano". Assim, intervimos para que as formas de vida escolares, a partir de suas experiências, vivam seu tempo giusto. Trata-se de governar o tempo e não ser governado por ele.

\section{DESCONCERTOS DE UM MUNDO QUE JÁ MORREU...}

Um mundo em pandemia que vivencia o desconcerto do isolamento social, mas também da aceleração das desigualdades de vidas, dos diferentes tipos de violência e fome e, os incontáveis valores de vidas perdidas. Um desconcerto inevitável, consonância volátil e, 
até o momento sem resolutividade, mas com uma força frágil, menor e marginalizada vibrante. Uma força inventiva que produz modos outros para nos reinventarmos, reexistimos e resistimos diante do que nos acontece em um mundo que já morreu. Assim, não trata de um desconserto que a todo custo quer retomar a normalidade, manter a economia e "seguir o baile". Que normalidade tinha esse mundo desencantado, violento, desigual, patriarcal e neoliberal? Onde o único conserto era a banalização de uma não vida à beira do esgotamento brutal.

O desconcerto, sempre singular e coletivo, compõe um dispositivo com "linhas outras de visibilidade, de enunciação, de força, de subjetivação, de brecha, de fissura, de fratura que se entrecruzam e se misturam, acabando por dar umas nas outras ou suscitar outras, por meio de variações ou mesmo mutações de agenciamento" (Deleuze, 1996, p.85). Essa sinfonia desconcertante provoca, sobretudo, estranhamento, desequilíbrio e suspeição de nossas práticas, mas ao mesmo tempo constitui inquietações sobre modos ainda não vividos em nossos assujeitamentos. Um desconcerto que faz com que percebamos aquilo que Sócrates dizia sobre seus adversários: são tão hábeis em falar que quase conseguem me fazer 'esquecer o que sou'.

O esquecimento de si causado também pela Fast School e intensificada pelo modelo educacional neoliberal, com princípios desigualitários, da economia capitalista e da sociedade de classes, provoca a negação do que nos acontece e no oportunismo de uma pandemia acentua com sutileza os próximos lances. O perigo de tal esquecimento de si e dos outros remete as reivindicações do retorno a uma normalidade não existente. Assim, a fácil saída parece permanecer na insistência da não vida, cuja pulsão se apresenta pela venda do tempo de vida e do capital humano produzindo sujeitos clientes a serviço da produtividade econômica.

Seguindo um fluxo outro podemos potencializar que o desconcerto proposto pela Slow School, onde o próprio slow se desloca dos sentidos de lentidão, ruim, improdutivo e preguiçoso, gera visibilidade e respiros de formas de vidas escolares outras na atualidade do presente. Oferece um mundo outro, podendo ser encantado, quando damos passagens a diferentes ritmos, velocidades e composições desconcertantes. 
Guimarães, J. \& Rodrigues, J. (2020). Afinando silêncios: potencialidades de escolas outras na atualidade do presente. Revista Latinoamericana de Etnomatemática, 13(1), 334-354. DOI:

10.22267/relatem.20131.50

\section{REFERÊNCIAS}

Couto, M. (2016). Antes de nascer o mundo. São Paulo: Companhia das Letras.

Foucault, M. (2011). A coragem da verdade: curso no Collège de France (1983-1984). Tradução Eduardo Brandão. São Paulo: Martins Fontes.

Deleuze, G. (1996) O que é um dispositivo? In G. Deleuze. O mistério de Ariana. (pp. 83-96). Lisboa: Vega.

Deleuze, G., \& Guattari, F. (1997). Mil Platôs: capitalismo e esquizofrenia, vol.5. Tradução Peter PálPelbart e Janice Caiafa. São Paulo: Editora 34.

Holt, M. (2006). A ideia da slow school: é hora de desacelerar a educação? In M. Stone, \& Z. Barlow (Orgs). Alfabetização Ecológica: a educação das crianças para um mundo sustentável. (pp. 87-94). São Paulo: Cultrix.

Honoré, C. (2005). Devagar. Tradução de Clóvis Marques. Rio de Janeiro: Record.

Laval, C. (2019). A escola não é uma empresa: o neoliberalismo em ataque ao ensino público. São Paulo: Boitempo.

Lévy, P. (1996). As tecnologias da inteligência. Rio de Janeiro: Edições 34.

Veiga-Neto, A. (2000) Educação e governamentalidade neoliberal: novos dispositivos, novas subjetividades. In G. Branco, \& V. Portocarrero (Orgs). Retratos de Foucault. (pp. 179 -217). Rio de Janeiro: Nau. 